\title{
Lecturers' Use of ICTs to implement the Curriculum at a Teacher Training College in Zimbabwe.
}

\author{
Dr. Starlin Musingarabwi \\ Lecturer; Midlands State University, Gweru, Zimbabwe.
}

\begin{abstract}
Typical job tasks entailed in implementing a college curriculum such as MS Power presentations in lectures, lecture preparation, research as well as teaching students at a distance require college lecturers in Zimbabwe to use ICTs. In most developed countries lecturers can now integrate ICTs in teaching. In Zimbabwe's teacher training colleges not much research-based evidence exists about how lecturers cope with the considerably new technologies in their work. This study sought to obtain information on lecturers' basic use of ICTs as a curriculum innovation that they should embrace in their work. The research employed the mixed-methods research design. I used questionnaires to collect data from a convenience sample of $\mathbf{1 0 0}$ lecturers and conducted interviews with five of the participants. A majority of lecturers indicated that they had irregular access to ICT facilities. They seldom or never used ICTs in their work. Focus group discussions revealed that inadequate ICT facilities including poor internet connectivity contributed to almost non-use of ICTs by most lecturers. Lecturers professed inadequate personal knowledge and skills to use a good number of the technologies. Findings of this study confirm the incidence of unsatisfactory use of basic ICT operations by lecturers at a college with meager functional ICTs. I recommend that the college provides enduring support to enable lecturers to evolve to the stage of proficient use of basic ICT operations for them to ultimately use ICTs for teaching.
\end{abstract}

Keywords: use of ICTs, integrating ICTs into teaching, electronic devices, curriculum innovation

\section{INTRODUCTION}

Unprecedented scientific and technological advancements in the form of electronic devices have driven many educational institutions the world over into embracing the idea of using the devices as a tool for educational tasks and teaching. This study adopts Adeyinka, Adedeji, Adika and Adeyinka's ( $\mathrm{n}$ d) conceptualization if ICTs as the use of the computer and other equipment created to enhance acquisition, storage and dissemination of information materials. The ICTs thus include the computer, internet, digital camera, mobile phones, data projectors, etc. In Zimbabwe, technological advancements that involve usage of the computer and e-based technological tools are fast gaining momentum in schools and higher education institutions. These technologies are relatively new to the relevant institutions and therefore serve as curriculum innovations to be embraced in implementing existing curricula.

According to Danner and Pessu (2013) most governments in the developed world have given top priority in training teachers in the use of ICTs and e-based applications as a way of enabling them to improve their teaching. By the same token, Zimbabwe's tertiary institutions have in the context of a generally under-resourced environment, made some considerable efforts to install and embed technology infrastructures and train the lecturers in colleges and universities for them to incorporate ICTs into their work. Chitanana (2014) maintains that as much as e-based learning is inevitably fast becoming part of the process of teaching and learning in Zimbabwe's schools, colleges and universities, a cause for concern is the presence 
of apprehension about technology adoption by many lecturers in universities and colleges. In teacher training colleges for example, lecturers need to use ICTs in their job tasks including lecture preparation, researching from the internet, presenting lectures to students using MS Power Point on projectors, using the spreadsheet for constructing and maintaining students' mark profiles, and communicating academically to students who are at a distance while on teaching practice, etc.

I contend that if at all lecturers are to be assisted to evolve to a stage where they can integrate the ICT technologies in their pedagogical practices with their students, baseline research based information on the state of affairs regarding their current access to and use of these technologies cannot be overemphasized. This is why this study was conducted to establish how lecturers are using the ICTs as an innovation for implementing the curriculum. The following major research questions thus structured and guided this study: What and how regular are the ICT devices to which lecturers have access for implementing the college curriculum? How regularly do lecturers use specific electronic devices for implementing the curriculum? How able do lecturers think they are in using specific ICT devices for doing their work?

\section{LITERATURE REVIEW}

Knowledge and proficiency in the use of ICTs lies at the heart of lecturers' adoption and utilization of the technologies in their work and classrooms. Emphasising the importance of use of ICTs in educational institutions, Burns (2010) maintains that educational instructors normally use technology for administrative tasks such as record compilation and record keeping, personal productivity, displaying and presentation of content to students through MS Power Point and document cameras. In consonance with Burns's (2010) observation, Rahimi and Yadollahi (2011) observe that educational instructors mainly use ICTs for instructional preparation, instructional delivery and as a tool used by students for learning. However, both these authors and Chitanana (2014) decry the situation that although educators use ICTs for various important purposes in their work, they rarely use them for teaching and learning of students in a real pedagogical sensibility.

In underlining the importance of ICTs to higher institution lecturers, Danner and Pessu (2013) argue that granted the benefits that accrue from adopting and applying the technology such as improvement in lecturers' teaching performance and student-centred learning, the use of technology should go beyond a basic technology literacy approach to focus on leveraging technology to transform the roles of the teacher and the learner in the classroom. Mbengo (2014) underscores the importance of the use of ICTs by lecturers by highlighting the benefits such as obtaining and disseminating new information to students from multimedia technologies and the internet. Mbengo (2014) further notes the benefits of bringing greater access to knowledge, improvement in archival capability of knowledge and the opportunities for student improvement as well as teaching effectiveness attendant to lecturers' integrating of ICTs to teaching.

I contend that for the lecturers to be able to adopt and use the vitally important technologies meaningfully, a profiling of their use of this innovation should not ignore a determination of the availability of basic resources and facilities and their access to them.

Adeyinke et al., (nd) observe that the availability of ICTs such as computers, e-mail, Internet, digital cameras, data projectors as well as regular access to these facilities is essential to educational instructors' use of the ICTs in their work. Ismail (n d) also argues that achieving a 
significant use of electronic and computer technology in the field of education can occur through factors such as availability and access to the devices. A study conducted by Bhukuvhani, Chiparausha and Zuvalinyenga (2012) at a Zimbabwean university revealed that lecturers' perceived lack of resources such as time, equipment, funding and lack of training hamstrung their use of the ICTs. A variable that is linked to and has a causal impact on the continued availability of the facilities and therefore is of interest in this study is the administrative dimension pertaining to the maintenance of the technology infrastructure installed in an institution. Ismail (nd) contends that if technical support and support services are insufficient and technical problems always occur in an institution, teachers may be less willing to use the technology in their work. Making a similar observation, Tanveer (2011) attributes lecturers' hesitation to use technologies to a lack of e-learning resources and a lack of full-time staff to monitor the electronic equipment. By implication, proper maintenance of the technology by the administration of a given institution means regular availability of the technology for the lecturers and a lack of it, irregular availability and therefore irregular use.

While the availability of and access to the technological facilities is crucial, on its own it does not fully explain the use of ICTs by lecturers. Chitanana (2014) aptly provides a comprehensive analysis of the adoption and use of technology by suggesting the socio-technical model. For him, the availability of ICTs alone cannot automatically guarantee their adoption and use by lecturers. Rather, a combination of the non-human material elements (technology) together with the human element (users of the technology) should in an analytical sense, constitute the use of the innovation. Thus, regardless of the ample availability of the facilities, without proper development of the intellect of the human users of the technology in terms of skills and knowledge, the use of the innovation remains largely symbolic. Conversely, no matter how proficient the human element is, in the inadequacy of technological facilities and resources, usage of the innovation is equally compromised.

In view of the observations made above, research has documented lecturers' knowledge of the use of ICTs as one of the key determinants of their use of technology. Findings of a study conducted by Tanveer (2011) at Majan University, Orman revealed that many lecturers cited perceived lack of technical skills and knowledge to use technology as an embarrassing and stressful experience in attempting to use it. These findings resonate with the findings from a study conducted by Adenike and Adedrian (2013) in some secondary schools in southwest Nigeria, in which teachers attributed their hesitation to use ICTs to their inadequate proficiency to use them. They admitted that they were incompetent to use the computer and related e-based tools for instructional activities such as Word Processing, Spread Sheet, MS Power Point presentations, Statistical tools and computer-aided instruction. Such a situation suggests that teachers are likely to stick to the traditional ways of instruction as they are implementing curricula.

A caveat to note in this study is that there exists a myriad of factors that determine lectures' use of ICTs, many of which interconnect to serve as barriers or challenges in themselves. Summarising some of these factors which have already featured earlier in this review may sound as repetition and yet for my purposes it re-emphasises the issues that need consideration in profiling the lecturers' use of the ICTs. In this connection, Bhukuvhani et al's (2012) study revealed that a perceived lack of knowledge by lecturers and the risk of attempting to use new technologies proved to be the most prohibiting barrier to use the electronic devices for teaching. Mandina (2015) also observes that factors endogenous to the educational instructors such as lack of confidence, lack of competence, resistance to change and negative attitudes serve as barriers to teachers' use of technology. In addition, external barriers such as lack of accessibility to e-based resources (Tanveer, 2011; Mandina, 2015), lack 
of time, lack of technical support in the classroom (Tanveer, 2011; Mandina, 2015; Ismail, nd) and the rigid structure of the education system could fuel educator resistance to change while a more progressive one could promote teacher acceptance and use of the innovation (Mandina, 2015).

In view of the foregoing review, it remains to be seen in this study the ICT gadgets to which lecturers have access for use in implementing their curricula, the uses to which they put them as well as how well they think they are able to use the gadgets.

\section{METHOD}

The study employed the mixed methods approach which included the use of questionnaires that were administered on a purposive sample of 100 lecturers working at the college, who consisted of 58 females and 42 males. In order to supplement and clarify issues from the survey data collected through questionnaires which consisted of closed-ended questions, semistructured interviews were held with ten (10) of the sampled lecturers. I quantified questionnaire data and analysed it using MS excel and presented in on tables of information. Along with descriptive statistical presentation of data was conducted a narrative description of the findings.

\section{RESULTS}

Data collected through questionnaires and interviews is presented and analysed below.

Table 1: Data on the hardware facilities to which lecturers have access, and the regularity of use of the facilities

$\mathrm{N}=100$

\begin{tabular}{|c|c|c|c|c|c|c|c|c|}
\hline REGULARITY & Always & & Sometimes & & Seldom & & Never & \\
\hline ITEM & $\mathrm{N}$ & $\%$ & $\mathrm{n}$ & $\%$ & $\mathrm{~N}$ & $\%$ & $\mathrm{~N}$ & $\%$ \\
\hline Personal Computer & 21 & 21 & 19 & 19 & 11 & 11 & 49 & 49 \\
\hline Laptop & 27 & 27 & 21 & 21 & 9 & 9 & 43 & 43 \\
\hline CD Player & 15 & 15 & 9 & 9 & 11 & 11 & 65 & 65 \\
\hline $\begin{array}{l}\text { Interactive white } \\
\text { Boards }\end{array}$ & 9 & 9 & 13 & 13 & 9 & 9 & 69 & 69 \\
\hline Tablet & 19 & 19 & 5 & 5 & 6 & 6 & 70 & 70 \\
\hline Digital Camera & 10 & 10 & 5 & 5 & 30 & 30 & 55 & 55 \\
\hline Cell phone & 35 & 35 & 13 & 13 & 9 & 9 & 43 & 43 \\
\hline Smart Phone & 17 & 17 & 11 & 11 & 5 & 5 & 67 & 67 \\
\hline
\end{tabular}

Data in Table 1 above indicates that generally the majority of lecturers did not have regular access to several hardware ICT facilities. Table 1 portrays a picture in which generally there is a greater number of lecturers $(50 \%+)$ who did not have access to and use hardware facilities across the board as compared to the number of those lecturers (less than 50\%) who used different hardware facilities across the board for doing their job tasks as they implemented the college curriculum. Data from Table 1 shows that $60 \%$ of lecturers did not access and use the personal computer with $49 \%$ having never had access to it and $11 \%$ seldom accessing and using it. A sizeable majority (48\%) accessed and used the laptop, with $27 \%$ always accessing and using it and $21 \%$ sometimes accessing and using it, while a staggering $52 \%$ seldom or never accessed and used this facility to implement the curriculum. Responding to the question 
on whether they used laptops for teaching preparation and actual teaching, 3 of the interviewed lecturers said that they had never owned a laptop as they did not have the financial resources to buy one. Twenty-four percent (24\%) of lecturers accessed and used the CD Player, with $15 \%$ of them claiming to access and use it always, and $9 \%$ sometimes accessing and using it. A vast majority of lecturers (76\%) indicated that they did not access and use this facility on a regular basis. While only $9 \%$ and $13 \%$ always and sometimes, accessed and used the Interactive White Boards, respectively, a staggering 9\% and 69\% seldom and never accessed and used it, respectively. Seventy-six percent (76\%) of lecturers did not have regular access to and use of the tablet, while $24 \%$ had access to and use of it (19\% always and $5 \%$ sometimes). A huge majority $85 \%$ (55\% indicating that they had never had access to and used a digital camera and 30\% indicating that they seldom accessed and used a digital camera) represents a gross irregular access to and non-use of this facility among the lecturers at this college. Conversely, $52 \%$ and $72 \%$ of the lecturers did not enjoy regular access to and use of the cell phone and the Smartphone in carrying out their job tasks as they implemented the curriculum. On the other hand, $48 \%$ and $28 \%$ of them at least accessed and used the cell phone and Smartphone, respectively. During interviews with lecturers regarding their access to and use of the above facilities, most lecturers indicated that they had never come across the CD Player, Digital Camera, Smart phone. Although almost every lecturer owned a personal cell phone, most of the interviewed lecturers confessed that they never used it for academic work to communicate with students for the main reason that it is expensive.

From Table 1, it can be discerned that generally lecturers had better access to and use of the Personal Computer, laptop, Cell phone, and Smartphone than the other hardware ICT hardware facilities such as the Digital camera, CD Player and Interactive White Boards.

Table 2: Data on the regularity of use of basic electronic devices for preparing lectures, teaching and student assessment.

$\mathrm{N}=100$

\begin{tabular}{|c|c|c|c|c|c|c|c|c|}
\hline REGULARITY & Always & & $\begin{array}{l}\text { Sometime } \\
\mathrm{s}\end{array}$ & & Seldom & & Never & \\
\hline ITEM & $\mathrm{N}$ & $\%$ & $\mathrm{~N}$ & $\%$ & $\mathrm{~N}$ & $\%$ & $\mathrm{~N}$ & $\%$ \\
\hline MS word & 32 & 32 & 28 & 28 & 20 & 20 & 20 & 20 \\
\hline $\begin{array}{ll}\text { MS } & \text { Power } \\
\text { point } & \\
\end{array}$ & 22 & 22 & 23 & 23 & 16 & 16 & 39 & 39 \\
\hline MS Excel & 22 & 22 & 17 & 17 & 18 & 18 & 43 & 43 \\
\hline Track changes & 16 & 16 & 10 & 10 & 16 & 16 & 58 & 58 \\
\hline Whats App & 21 & 21 & 20 & 20 & 22 & 22 & 37 & 37 \\
\hline Internet & 18 & 18 & 17 & 17 & 22 & 22 & 47 & 47 \\
\hline
\end{tabular}

Table 2 above shows that considerable majorities of lecturers (56\%; 45\% and 41\%) enjoyed regular use of electronic devices, namely MS Word for typing plans and lecture notes, MS PowerPoint for presenting lecture notes to students, and WhatsApp to chat with students on academic work, respectively. A good $40 \%$ of lecturers did not use MS Word for typing their plans and lecture notes on a regular basis as $20 \%$ of them indicated that they seldom used it while 20\% never used at all. Fifty-five percent (55\%) did not use MS PowerPoint for presenting lecture notes to students. Of concern to note is that vast majorities of lecturers (61\%; 74\%; and 65\%) did not regularly use MS Excel for preparing students mark profiles, Track changes for marking assignments and internet to communicate with students on academic work, respectively. 
Table 3: Data on lecturers' ability to the use electronic devices for preparation of lectures, teaching and student assessment

$\mathrm{N}=100$

\begin{tabular}{|l|r|r|l|l|l|l|l|l|l|l|}
\hline Ratings & Unable & & \multicolumn{2}{|l|}{$\begin{array}{l}\text { A bit } \\
\text { able }\end{array}$} & & Undecided & & Able & & \multicolumn{2}{l|}{$\begin{array}{l}\text { Very } \\
\text { able }\end{array}$} & \\
\hline Frequency & $\mathrm{N}$ & $\%$ & $\mathrm{n}$ & $\%$ & $\mathrm{n}$ & $\%$ & $\mathrm{~N}$ & $\%$ & $\mathrm{n}$ & $\%$ \\
\hline ITEM & & & & & & & & & & \\
\hline MS Word & 21 & 21 & 24 & 24 & 1 & 1 & 31 & 31 & 23 & 23 \\
\hline $\begin{array}{l}\text { MS Power } \\
\text { point }\end{array}$ & 26 & 26 & 22 & 22 & 14 & 14 & 21 & 21 & 17 & 17 \\
\hline MS Excel & 23 & 23 & 30 & 30 & 11 & 11 & 23 & 23 & 13 & 13 \\
\hline $\begin{array}{l}\text { Track } \\
\text { changes }\end{array}$ & 40 & 40 & 20 & 20 & 10 & 10 & 18 & 18 & 12 & 12 \\
\hline Whats App & 29 & 29 & 21 & 21 & 0 & 0 & 28 & 28 & 22 & 22 \\
\hline Internet & 34 & 34 & 20 & 20 & 3 & 3 & 24 & 24 & 19 & 19 \\
\hline
\end{tabular}

Data in Table 3 above indicates that vast majorities of lecturers (53\%; 60\%; 50\%; and 54\%) did not possess the ability to use electronic devices, namely MS Excel for preparing students' mark profiles, track changes for marking assignments, Whats App to chat with students on academic issues and internet to research and communicate with students on academic work, respectively. Although significant numbers of lecturers represented by $54 \% ; 51 \%$ and $41 \%$ professed knowledge and skills to use MS Word for typing plans and lecture notes; Whats App to chat with students, and internet to communicate with students respectively, the numbers of lecturers who were unable to use the same devices were more or less equally significant. Forty-five percent (45\%) of them did not know how to use MS Word; 50\% did not know how to use Whats App while 54\% were unable to use the internet.

\section{DISCUSSION}

At this Polytechnic college it emerged in this study that the vast majority of lecturers sorely indicated a gross lack of access to and regular use of cardinally important ICT technologies that promote efficient performance of their key job tasks and student learning. Granted the common existence of the ICT technologies that were installed in most of Zimbabwe's higher learning institutions, it is interesting to note that several lecturers at this college (See Table 1) indicated total ignorance of the Digital Camera, CD Players, Interactive White Boards and the Smart Phone. They said they had never seen them at all, much less used them. Responding to an interview question on the access to and use of ICT hardwares, some lecturers attributed their limited access to and use of technologies such as Interactive White Boards to the college administration's lack of concern about ensuring that these gadgets are in place. Some lecturers cited poor maintenance of the installed ICT equipment in the college's computer laboratory as a factor that made them distanced from ever wanting to access and use the technologies. One Participant stated: Most of the equipment and computers in our lab are not really working. Authorities do not maintain them well, or they don't replace the computers that are out of order. So I just prepare and teach my students even without these gadgets.

This finding concurs with the findings of studies conducted by Tanveer (2011) and Mandina (2015) which revealed the lack of accessibility to e-based resources as a stumbling block to the use of ICT technologies by teachers. The seriously negative implications that such a scenario has for the lecturers' delivery of the curriculum and student learning cannot be overemphasized. A situation in which the college' s authorities fail to maintain those gadgets 
that the college already possesses and replenishes their availability may suggest that the adoption and use of modern ICT technologies that educators are called upon to embrace may still remain a far cry at this particular institution.

My interest in establishing how regularly lecturers use basic electronic devices for preparing lectures, teaching and student assessment is addressed by the findings that point to a general picture in which vast majorities of the lecturers indicated irregular use of a wide range of the ICT technologies. For example, (55\%) did not use MS PowerPoint for presenting lecture notes to students, and vast majorities of lecturers (61\%; 74\%; and 65\%) did not regularly use MS Excel for preparing students mark profiles, Track changes for marking assignments and internet to communicate with students on academic work, respectively. By implication these lecturers did not incorporate into their core and routine job tasks the ICT innovation- a situation that suggests that several teachers have not yet started to institutionalise the innovation as part of their teaching practice. This finding contrasts with Mbengo's (2014) observation that ICTs can enable lecturers to obtain and disseminate new information to students from multimedia technologies and the internet. It means that if lecturers do not regularly use MS Powerpoint to present lectures and Track changes to mark students'work, they are likely to be still using the laborious chalk- and-talk method of teaching and the penciland-paper method of producing students' mark profiles. They are thus deprived of access to new information that abounds in e-learning sources of which a lecturer should be abreast in order to optimalise successful student learning.

In contrast to the foregoing scenario, findings of this study also portray a positive picture in which considerable numbers of lecturers enjoyed regular access to and use of key electronic devices such as MS Word, MS Powerpoint, and WhatsApp. The encouraging situation suggests that if the college authorities and the lecturing staff were to do everything within their spheres of influence to uplift the institutionalization of this innovation, the current gains could be a sound springboard from which to embrace the innovation into normal practice.

Findings of this study revealed that vast majorities of lecturers indicated that they were not able to use a wide range of electronic devices to implement college curriculum. One lecturer asked in an interview to substantiate her inability to use the devices said that she had never learned how to use the devices owing to lack of time, too much work and inadequate facilities. She also stated that even if training workshops were held they were not enough for her to learn the technologies. Another lecturer intimated that he found it difficult to learn and use the gadgets and e-based facilities in his teaching. He argued that he did not even need to use internet facilities as he had no e-mail address at all. These findings suggest that several lecturers were almost non-users of the ICT innovation. To many of them their inability to use the technologies rendered the innovation enigmatic to them. The finding resonates with findings from a study conducted by Tanveer (2011) at Majan University, Orman which revealed that many lecturers lacked technical skills and knowledge to use technology and encountered an embarrassing and stressful experience in attempting to use it. These findings underline the incidence of unsatisfactory use of basic ICT operations by lecturers at a college with meager functional ICTs and inadequate staff development workshops to enable the lecturers to use them. By implication if the inability to use ICT technologies by lecturers is to persist unchecked, then it is unlikely that the transcendence from traditional teaching techniques into use of $21^{\text {st }}$ century technologies will ever occur so soon at this college.

\section{CONCLUSION}

Findings of this study revealed that generally most lecturers at this college did not enjoy regular access to and use of hardware facilities for implementing the college curriculum. The 
general unavailability of the gadgets in the college and non-possession of some basic but crucial devices by lecturers hamstrung regular access to and use of electronic devices. As a curriculum innovation that was meant to promote effective student learning in vogue with $21^{\text {st }}$ century technology, ICTs at this college were not being used by the lecturers. Lecturers' poor abilities in use of electronic devices degenerated to almost non-use of the ICT technologies in a college where every lecturer in a higher learning institution is expected to implement the curriculum innovation for effective implementation of the college curriculum. I recommend that the college administration should source enough devices and ensure that these are maintained in working order including internet connectivity. College should intensify and regularize staff development workshops to equip lecturers with knowledge and skills in general computer literacy and specific use of ICTs.

\section{References}

Adenika, O.C. \& Adedrian, A.A. 92013) Social Studies Lecturers Proficiency in the Use of Computers for Effective Teaching in Colleges of Education In the South West Nigeria. Journal of Economics and Sustainable Development. 4(8): 201-215.

Adeyinka, T., Adedeji, T., Adika, L.0 \& Adegumbe, A.A (n d) An Assessment of Secondary School Teachers' Uses of ICTs: Implications for further Development of ICT's Use in Nigerian Secondary Schools. Available at:631teachersictuse.pdf-AdobeReader [Accessed, 20 October, 2016].

Bhukuvhani, C., Chiparaushe, B.\& Zuvalinyenga, D. (2012) Effects of Electronic Information Resources Skills Training for Lecturers on Pedagogical Practices and Research Productivity. International Journal of Education and Development using Information and Communication Technology (IJEICT) 8(1):16-28.

Chitanana, L. (2014) A Change in University Lecturers' Perceptions of E-learning Tools for Intsructional Delivery at Midlands State University: From Techo-phobic to Technology Savvies. ISSN 2223-7062Proceeedings and report of the $7^{\text {th }}$ UbuntuNet annual conference, 2014, pp83-98.

Danner, R.B.\& Pessu, C.O.A (2013) a Survey of ICT Competencies among Students in Teacher Preparation Programmes at the University of Benin, Benin City, Nigeria. Journal of Information Technology Education: Research.12:5-13.

Ismail, I., Bhokare, S.F.Azizan, S.N. \& Azman, N. (n d) Teaching via Mobile Phone: A Case Study on Malaysian Teachers' Technology Acceptance and Readiness. Available at:IsmailCTeachers.pdf-Adobe Reader

Mandina, S. (2015) Integrating ICTs into the Environmental Science Primary School Curriculum in Chegutu District, Zimbabwe: Problems and Solutions. European Journal of Science and Mathematics Education. 3 (1): $90-96$.

Mbengo, P. (2014) E-learning Adoption by Lecturers in Zimbabwe selected State Universities: An Application of Technology Acceptance Model. Journal of Business Administration and Education. 6 (1) : 15-38.

Rahimi, M. \& Yadollahi, S. (2011) ICT Use in EFL Classes: A Focus on EFL Teachers' Characteristics. World Journal of English Language. 1(2):17-29.

Tanveer, M. (2011) Integrating E-learning in Classroom-based Language Teaching: Perceptions, Challenges and Strategies. International Conference "ICT for Language Learning" $4^{\text {th }}$ edition. 